\title{
Water and Communities in South Asia: A Case for Regional Cooperation
}

\author{
Dr Venkat Pulla, ${ }^{+*}$ Dr Zahid Shahab Ahmed'i and Dr Manohar Pawar
}

\section{Abstract}

Increased use of water for hydropower and agriculture, due to population growth accounts for future water shortages that will affect a quarter of South Asia's population by 2050. Water crises affect all member-nations of the South Asian Association for Regional Cooperation (SAARC), namely Afghanistan, Bangladesh, Bhutan, India, Maldives, Nepal, Pakistan, and Sri Lanka. SAARC nations water needs exacerbate the water crisis on the one hand and lack of mechanisms for good governance and cooperation required for addressing issues related to food and water security within the region. This paper attempts to draw attention to the big picture regarding water resources management and the impacts of water scarcity on South Asian nations. The paper begins with a review of the water crises in each of the SAARC nations and follows on with consideration of perceptions towards transboundary river infrastructures and the political stances each nation takes about solutions for the continuing water crisis. Undoubtedly, the only mechanism that these nations can adapt to address the geopolitical challenges of a thirsty world, for which SAARC association provides the platform is a deliberate constructive solution centred dialogue. A range of recommendations for SAARC nations are reviewed with a view to assist the water thirst in these nations.

Keywords: Transboundary Rivers, Indo-Pak Waters, Himalayan Water Disputes, Water and Human Services, SAARC Countries

\footnotetext{
${ }^{+}$Adjunct Senior Research Fellow, Institute for Land Water and Society, Charles Sturt University, Albury-Wodonga, NSW, 2640, Email: dr.venkat.pulla@gmail.com, vpulla@csu.edu.au

${ }^{*}$ Corresponding Author

'̇ Research Fellow, Alfred Deakin Institute for Citizenship and Globalization, Deakin University, Australia, Email: zahid.ahmed@deakin.edu.au

İ Professor of Social Work, Member, School of Humanities and Social Sciences, Locked Bag 678, Charles Sturt University, Wagga Wagga, NSW, 2678, Australia. Email: mpawar@csu.edu.au

(C) 2018 Pulla et al. This is an Open Access article distributed under the terms of the Creative Commons Attribution License (http://creativecommons.org/licenses/by/2.0), which permits unrestricted use, distribution, and reproduction in any medium, provided the original work is properly cited.
} 


\section{Introduction}

Water is life on Earth, yet over 844 million people seem to lack access (Guppy and Anderson, 2017). From being free and common source available to all it has become a commodity in most parts of the world. Children fetch water and miss out on schools and 200 million hours are lost each day in this age. In the countries of sub-Saharan Africa, it is said that it takes over 30 minutes to walk and fetch a bucket of water with over 3.36 million children involved in such water collection (UNICEF 2016).

A man married three women to keep a constant supply of water in a parched region in Maharashtra, India. ${ }^{1}$ While the world may term this a criminal offence, it drives home a pathetic message that women and girls are the only ones at the front end of fetching water, which in turn becomes a big chore to keep each of their families alive. In Cholistan desert in Pakistan, "the long drawn tribulations of women include walking miles for a vessel of water" (Shoukat \& Pulla, 2017: 34). Similarly, studies reveal that in the mountainous regions of Uttarakhand, India, the women and girls walk for miles along the undulated landscape to fetch water (Singh 2014; Singh, 2015).

Access to clean water indeed changes everything. True, water is life, but, many nations in Asia burgeoning with economic growth show a ground reality that points to shocking water insecurity. This is a dilemma that afflicts even industrialised countries. New Mexico in the United States has only ten years' worth of drinking water left while Arizona already imports every drop (Kugelman, 2011). The year 2025 is a not far away. A report by the World Commission on Water for the 21st century prepared numerous scenarios for possibilities about water on planet earth. The grim possibilities noted have been that most developing countries will reel under 'water

\footnotetext{
${ }^{1}$ Man Marries three wives in India, TV, C. (2015, June 05), retrieved 30 October 2018, from https://www.youtube.com/watch?v=7brs2NXzD7Q
}

stress $^{\prime}{ }^{2}$ the increase of this stress will be felt in South Asia, Southern and Western Africa (Alcamo et al, 2000). An attitude and practice of 'business as usual' (BAU) that is largely prevalent in withdrawals of water across industrialised and developing countries is predicted to contribute to severe water stress and these according to the World Commission on Water are influenced by growing technology, economic demands and increased private sector involvement and also as a result of changing values and lifestyles (Alcamo et al., 2000).

In the following pages, Figures (1-3) amply illustrate the gender and water crisis. Figure 1 is based on a report from Kathryn Reid (2018) of World Vision, an international non-governmental organisation. Figures 2 is illustrative of how a little girl is involved in fetching water for their families; Figure 3 illustrates girls and women paying "freshwater tribute to the sea" on March $13^{\text {th }}$, 2018, in Clifton Karachi, Pakistan at Sea View beach. Participants carried two dozen clay pots filled with fresh water and poured them into the sea as a token of respect little drinking water directly from a water tap". ${ }^{3}$

Water resource management in South Asian Association for Regional Cooperation countries, abbreviated as SAARC region can be described as a story of considerable debate and hostility spanning across decades of unfolding disaster (Basu \& Shaw, 2013). Despite six decades of discussion among SAARC members, most areas of South Asia remain on the edge of a catastrophic water disaster (Price et al, 2014). Discussions around water in SAARC countries, particularly around transboundary rivers (that

\footnotetext{
2 According to the glossary of United Nations Environment Programme, UNEP, water stress occurs when the demand for water exceeds the available amount during a certain period or when poor quality restricts its use. GreenFacts: Facts on Health and the Environment, retrieved on 30 July 2018 from, https://www.greenfacts.org/glossary/wxyz/waterstress.htm

${ }^{3}$ From Rivers to Oceans, International Rivers, retrieved 28 September 2018 from, https://www.flickr.com/photos/internationalrivers/4479 138577/
} 
is, rivers that flow across international borders), have become increasingly tense and antagonistic as water scarcity increases and countries independently plan to secure their own water sources (Earle, Jagerskog-, \& Ojendal, 2013). The issue of transboundary rivers is highly politicised in South Asia. A history spanning more than 50 years surrounds all types of proposals for infrastructures within each of these countries. Ameliorative and public policy proposals of successive governments and the private sector are received with distrust and resistance from different political, humanitarian and environmental groups based on respective ideologies and belief systems. The debate ensues with estimated negative impacts on land, flora, fauna and people, their livelihoods and their habitats.

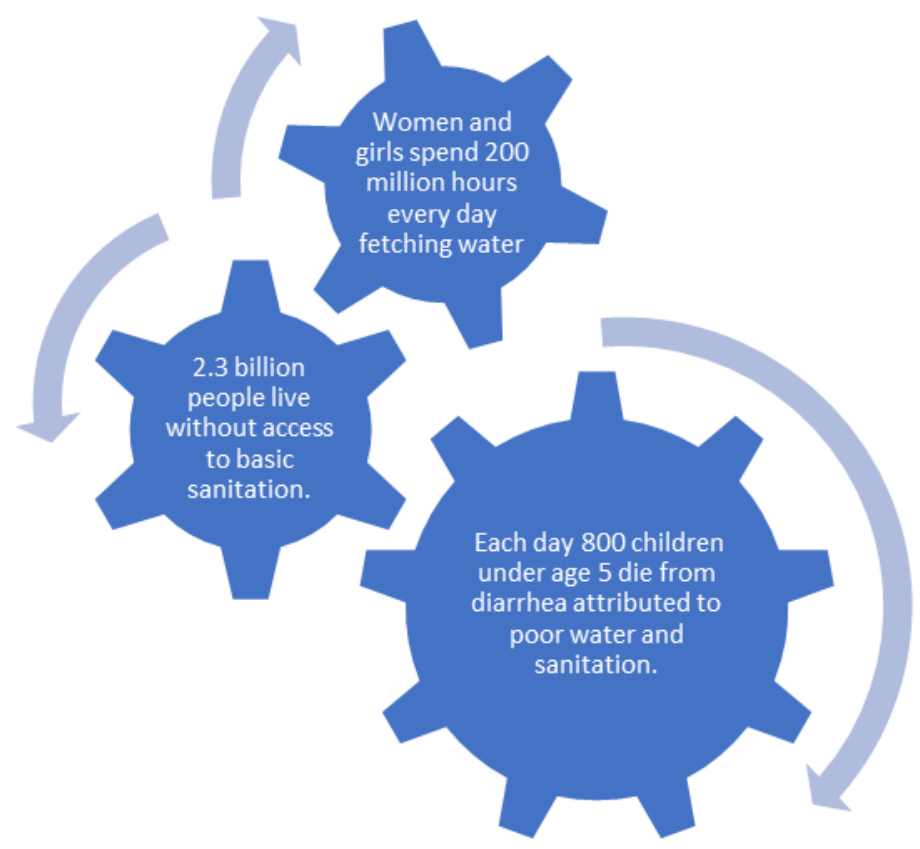

Figure 1: Adapted from World Vision, 2018 report

Reid, K. (2018, May 17). Global water crisis: Facts, FAQs, and how to help, retrieved on 30 May 2018 from, $\mathrm{https} / / / \mathrm{ww} w$. worldvision.org/dean-water-news-stories/global-water-crisis-facts

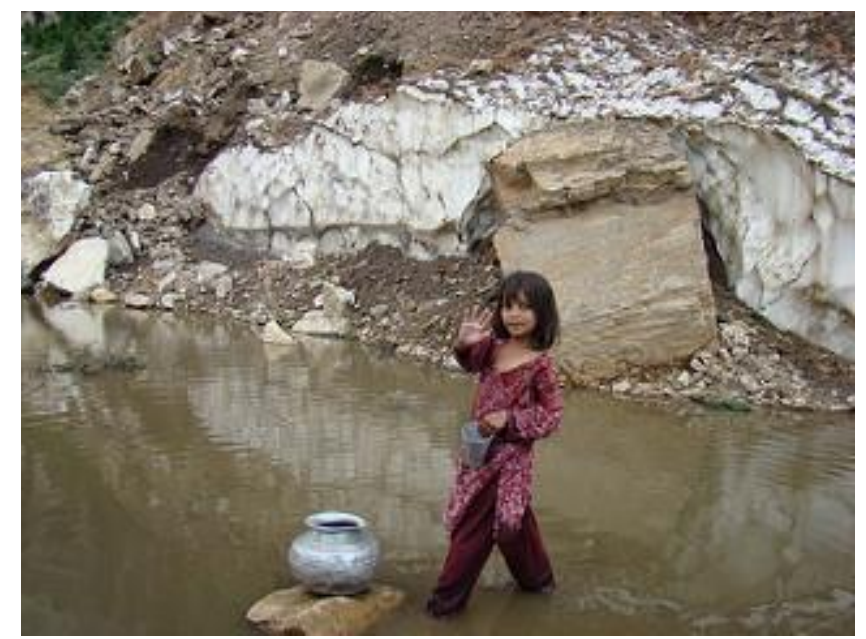

Figure 2: A Little Girl about to Fetch Water

Source: Innocent Faces, Photo courtesy of Abeer J.Chaudhri, retrieved 27 October 2018 from, https://www.flickr.com/photos/abeerjabbar/3774977021/ 


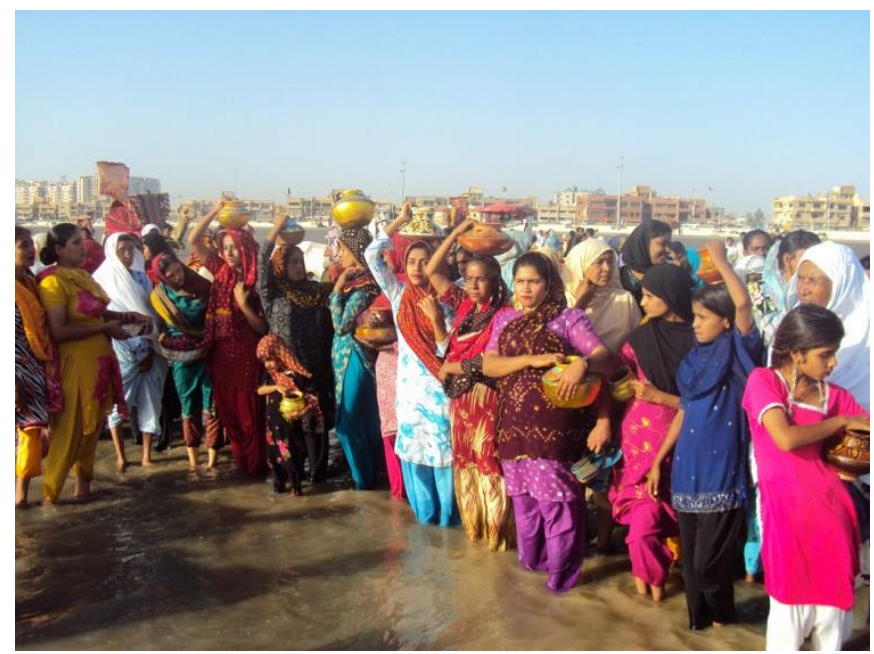

Figure 3: From Rivers to Oceans, International Rivers, Photo courtesy of Zubeda Birwani, retrieved 28 September 2018 from, https://www.flickr.com/photos/internationalrivers/4479138577/

The water resources of a country have a significant impact on the social, economic, and environmental state of not only the country from where rivers originate (Qaddumi, 2008; Uprety \& Salman, 2011) but also have similar impacts in lower riparian countries sharing the Transboundary Rivers. Water itself is a fundamental resource; it is vital to maintaining secure ecosystems and adequate living circumstances for humans and animals (Mastoor, 2009; Qaddumi, 2008). Food production, industrial expansion, transportation of goods, drinking water, and energy supply are reliant on water accessibility (Earle et al., 2013; Qaddumi, 2008). Poverty, low education levels, child mortality, health and sanitation practices are linked to lack of access to clean drinking water (Pawar, 2014). This paper aims to identify strategic ways of resolving South Asia's water crises and draws attention to the following objectives:

- To present an overview of Water Resources and People-Centred Issues in SAARC Nations;

- To present the transboundary water views of SAARC countries;

- To present the role of SAARC and the association's response to current and emerging water crises; and

- To present the implications of current and emerging water crisis issues on service deliveries.
The article begins with a discussion of peoplecentred issues linked to water access in all the SAARC countries. Following this, it discusses the transboundary water disputes amongst the SAARC nations. It then goes on to discuss the relevance of Social Work practice in challenging water crises. In the final section, it discusses the responses of SAARC nations and its cooperation with ASEAN for possible solution to the water crises of these nations.

\section{Water Resources and People-Centred Issues in SAARC Nations}

Across the SAARC region, water resource management has been primarily assessed as inadequate (Price et al., 2014). The main challenges for governments are said to be due to ever-increasing population, domestic and international conflict, domestic mismanagement, and deteriorating quality of water, and cultural practices (Basu \& Shaw, 2013; Pawar, 2014). Many policies have been established to combat water issues, for example, the 1999 Water Law in Bangladesh that received considerable attention, despite a visible gap between the rhetoric and actual implementation (Gupta et al, 2005). Other SAARC members also face significant water management challenges due to two major river systems, that is, the Ganges-BrahmaputraMeghna and the Indus-Kabul (Price et al., 2014). Clearly, these river systems are dependent on glacial melting from the Himalayas, and summer monsoons and the 
flow of water fluctuates in different seasons, for instance, an extreme example is of flooding that comes with monsoons. Often policies fail due to poor coordination between central or federal governments, local officials, and their state or provincial government ministries. In the following sections, we bring in a country wise discussion on water issues.

\section{The Case of Afghanistan}

The case of Afghanistan is unique because the ongoing war has destroyed much of the infrastructure and it is practically impossible to build infrastructures in areas not under its control (Reich and Pearson, 2012). Afghanistan-a landlocked SAARC state-is estimated to be water-stressed by 2024 and water scarce by 2045 (Basu \& Shaw, 2013). The country's yearly surface resource of water is estimated to be $57 \mathrm{~km}^{3}$ which is distributed and managed by five river basins. Each person should, in theory, be supplied with 2,775 $\mathrm{m}^{3}$ of water per year. However, only two rivers (that is, the Panj-Amu and Kabul) contain enough water resources, and neither have a large human population surrounding nor large areas of land for agriculture. This situation is further stressed by the poorly located and poorly planned hydropower structures along rivers that threaten the availability of irrigation water (Price et al., 2014). Inadequate availability and sanitation of water, and dire standards of living highlight Afghanistan as a country containing high poverty levels (Basu \& Shaw, 2013). Afghanistan's water management issues are generally said to be due to bad governance, especially involving corruption (Price et al., 2014). Due to this, the country relies heavily on international non-government organisations, the European Union and the United Nations to fund water management strategies.

\section{The Case of Bangladesh}

Bangladesh is a delta formed by the GangesBrahmaputra-Meghna system. It is dependent on water flow from an upstream neighbour, resulting in severe concerns in water-sharing with India which involve issues related to judicious allocation, flood control, and famine mitigation (The London Post, 2017). Bangladesh will likely face water scarcity and severe depletion by 2050 (Basu \& Shaw, 2013). The country receives yearly rainfall of 250 cubic $\mathrm{Km}$ and flows from transboundary rivers totalling 1,000 cubic $\mathrm{Km}$. However, up to 1,230 cubic $\mathrm{km}$ is lost as run-off annually and 88 per cent of the remaining available water is used for irrigation indicating that the country suffers from severe water shortages, especially among the rural population with per capita annual water availability of the only 247 cubic $m$.

Bangladesh is the end user of river water and has no control over the upstream flow, which reduces water availability during the dry sessions and causes significant flooding during monsoon seasons. Water disputes between India and Bangladesh include Farakka Barrage or India's large dams to increase the dry season flow of the Ganges, an ad-hoc water-sharing agreement over Teesta River signed in 1983 between the two countries, and India building a dam at Tipaimukh over the international river Barak. Besides, the river water is highly polluted, and contamination from arsenic means the groundwater is generally unusable (Basu \& Shaw, 2013). The Teesta river dispute cropping up every time during bilateral talks between India and Bangladesh highlights the unresolved conflict about water sharing of river Teesta with Bangladesh demand for increasing its share to $50 \%$ and a fair share especially during the dry season from the current share of 37.5 per cent as per Interim Deal of 2011 supposed to be lasting for 15 years. Teesta is the fourth largest transboundary river shared by India and Bangladesh after Ganges, Brahmaputra and Meghna rivers. With a lack of treaty policies applied to transboundary waters, Bangladesh experiences water supply problems when India withdraws or diverts water flow (Price et al., 2014). Bangladesh's water management issues are generally said to be due to a lack of coordination and mistrust between Dhaka and New Delhi (Biswas, 2011). However, in 2017 the government of Modi and Sheikh Hasina agreed upon to engage in dialogue over disputed Teesta water-sharing issue. 


\section{The Case of Bhutan}

Bhutan has limited groundwater resources, and therefore the country survives mainly on the 73 cubic $\mathrm{km}$ of internal renewable surface water resources it receives per year. The annual water per capita of the country is 75,000 cubic $m$ due to a small population of around 750,000 citizens. However, increased agricultural purposes and seasonal water shortages at times push the country into water scarcity (Basu \& Shaw, 2013). Furthermore, the majority of water for domestic and drinking purposes must be fetched at a long distance from springs and streams located far from communities. India- Bhutan cooperation in hydroelectric power projects is more than five decades old and both countries signed in 2006 a power purchase agreement for 35 years wherein India will generate and import 10,000 MW from Bhutan. Bhutan's options for improving water storage capacity are dependent on the cooperation of lower riparian neighbour- India.

\section{The Case of India}

India, the most prominent South Asian country, experiences rapid irrepressible economic and ecological expansion. Consequently, there has been an increased use and need of water for human consumption, agriculture, and hydropower. A lack of infrastructure around containing and treating water, increased scarcity and pollution of fresh waters, preventing wastage of water and augmented water needs for hydropower and agriculture (Price et al., 2014) due to population increase, are just the tip of a water disaster set to affect one in four South Asian people by 2050 (Memon, 2014). In 2009, India's water supply needs were estimated to be 740 billion cubic $m$ by 2030 , but it is estimated to increase up to 1,500 billion cubic m (HDC, 2013). Recently, the government of India revived plans for interlinking of river systems (that is, the National River Linking Project) as an intervention for the worsening Indian water crisis (Mohan, 2014), Not without criticism from many prominent experts and personalities, that the ambitious project of becoming "biggest water transfer project in the world" will be a financial, social and environmental disaster (Joshi, 2013). This biggest water transfer project involves linking the current unevenly distributed water resources of India to improve water management and sanitation (Mohan, 2014; Uprety \& Salman, 2011). Such a plan is estimated to cost more than US\$120 billion and will affect the downstream transboundary river flows of the Ganges-Brahmaputra-Meghna and the Indus-Kabul. Therefore, the water supplies of Bangladesh, Nepal, and Pakistan are likely to be negatively affected, feeding the already tense conflictual relations between India and Pakistan.

An explosion in urbanisation, thirsty agriculture, ever-rising population, and changing lifestyles are the challenges for the biggest SAARC country, India, already experiencing an ongoing water crisis. According to an estimate, India will become water stressed by 2020 and water scarce ${ }^{4}$ by 2025 (Basu \& Shaw, 2013). The annual per capita of water for the country was $1,820 \mathrm{~m}^{3}$ in 2001 . However, this has drastically decreased to $630 \mathrm{~m}^{3}$ in recent years. A recent study found that water inequalities, inequities, and injustices in India have always existed, with huge extremes between the water-rich and the water-poor across class, caste, and gender, across regions and between cities and rural areas" (Roth et al, 2014). The availability of water across the country is severely unevenly distributed due to varying groundwater reserves, rainfall, and proximity to rivers (Basu \& Shaw, 2013). Seventy-one per cent of water resources are supplied by one of the major water supplying rivers (that is, the GangesBrahmaputra-Meghna) that run through the country; which unfortunately can only be reached by $36 \%$ of the population (Basu \& Shaw, 2013). The remaining $64 \%$ of the

\footnotetext{
${ }^{4}$ The supply and demand mismatch in India is expected to turn India into a water scarce nation by 2025 as per a report by India, H. (2016, March 13). 'Water to be scarce by $2025^{\prime}$, retrieved 28 August 2018 from, http://www.thehansindia.com/posts/index/NewsAnalysis/.../Water...scarce...2025/213412
} 
population survive on $29 \%$ of other water resources (Basu \& Shaw, 2013; Price et al., 2014). India's water management issues are generally said to be linked to the government's intense focus on industry. For example, the government has given way to allowing CocaCola to build a plant in Sanand, which will syphon three million litres of water from the Narmada River per day and cause further water supply issues to the area (Nair, 2014; Patkar, et al, 2014). 'Despite industrialisation, agriculture is still a vital industry in India with a share of a quarter in the GDP, and nearly 75 per cent of the population depend on this sector' (Roth et al., 2014: p.957).

\section{The Case of the Maldives}

The Maldives has already passed the point of water scarcity. There is no access to rivers, streams, or lakes, meaning, water supply is dependent on rainwater, desalinated seawater, and heavily contaminated groundwater. Previously, the country was heavily reliant on access to freshwater. Due to population increase, poor agricultural practices, pollution by salt water, and industrial and human sewage, rainwater and desalinated seawater is now the primary source of drinking water and groundwater is used for all other purposes (Basu \& Shaw, 2013). The country suffers severely due to lack of land space, presenting difficulties in construction of roof catchments and storage for rainwater is difficult; therefore, desalination of seawater is the main method for bigger cities such as Malé (Basu \& Shaw, 2013). Although desalination is expensive, citizens have no other alternative; the cost to an average household is equivalent to $6-9 \%$ of the household's monthly income (that is, approximately $\$ 40-\$ 60$ per month of a typical $\$ 668$ monthly salary (Basu \& Shaw, 2013).

The Maldives, and to a lesser extent Sri Lanka, face a major water management crisis. As islands, both countries sit disconnected from mainland South Asia and rely heavily on groundwater, rainwater and seawater to sustain life, and industrial and agricultural requirements (Basu \& Shaw, 2013; HDC, 2013).

\section{The Case of Nepal}

Nepal is one of the poorest landlocked countries in the world and as home to glacial Himalayas, is expected to be one of the worst countries affected by climate change. The country receives over 210.2 billion cubic $\mathrm{km}$ of renewable water sources yearly. However, only 359 cubic $m$ of water is available per capita annually (Basu \& Shaw, 2013; Price et al., 2014). Less than half of the country has irrigated farmland, more than one-third of the population faces difficulty in gaining access to water, and many people living on the mountains are unable to access clean drinking water flowing in the valleys below (Basu \& Shaw, 2013). These issues are due to a lack of storage capacity and infrastructure, as well as high levels of sediment in rivers and uneven water distribution (Basu \& Shaw, 2013). Nepal's water management issues are generally said to be due to poor governance. Regional cooperation is a critical concern for food and water security of Nepal which is dependent on Ganga-Brahmaputra-Meghna basin. Old Agreements and Treaties about rivers Kosi, Gandak and Mahakali have been a source of mistrust and suspicion in India-Nepal relations and talks about Karnali, Pancheswar, and Sapta Kosi have been contested with little signs of resolution for about four decades (Iyer, 2008, 2010). Plans and policies are in place, but there is a lack of coordination among concerned public offices. Therefore water management issues are slow to improve (Price et al., 2014).

\section{The Case of Pakistan}

Pakistan became water stressed in 2000 and is on the verge of becoming water scarce. Only 1,090 cubic $m$ of water is available to each person per year, well below the 1,700 cubic $m$ per capita annual water stressed minimum (Basu \& Shaw, 2013). The population in 2010 was 184.8 million and is growing rapidly to the point and is expected to be over 240 million by 2030 (Ebrahim, 2016). Such significant increases in population have forced large volumes of water from the Indus-Kabul to be diverted to the leading agricultural province of Punjab. This diversion has led to the river 
becoming a canal in the downstream province of Sindh (Basu \& Shaw, 2013). Agriculture consumes around 97 per cent of water in Pakistan leaving only three per cent for human consumption and industry (Kamal, 2009). Poor management, unequal distribution, and limited rainfall indicate that Pakistan will worsen further into severe water crisis shortly (Iqbal, 2010). Pakistan's water management issues are generally said to be due to the government's intense focus on agriculture. High diversion of water resources to the needs of the agriculture and industry is having a very negative impact on citizens' abilities to access clean drinking water in many areas.

\section{The Case of Sri Lanka}

Sri Lanka is cut off from the mainland South Asia and survives on internal renewable water resources, that is, groundwater, rivers, and streams and eighty-five per cent of which are withdrawn to assist in irrigation (Basu \& Shaw, 2013). The remaining water resources supply around $2,530 \mathrm{~m}^{3}$ of water to each person annually. However, only 35 per cent of the country's 20 million people receive water straight to their homes. Around 65 per cent of the country's citizens travel vast distances to retrieve fresh water from the rivers, streams, and wells; a job often undertaken by women and children (Basu \& Shaw, 2013). Due to industrialisation and increasing population, Sri Lanka is predicted to be low to moderate water scarce soon (Amarasinghe et al, 1999).

\section{Transboundary Waters and Bilateral Disputes}

Water seems to keep the people of each nation united or at times divided within the countries with political parties claiming and producing regional water disputes within all countries in the SAARC region more particularly in current times (Swain, 2018). The assessment of cooperation on sharing waters from transboundary waters in South Asia depicts a mix of successes and failures. While there is an example of good water sharing between Bhutan and India, issues plague downstream water supply of neighbouring countries, with concerns that arise around the impact of constructing infrastructures such dams, hydropower, and sanitation plants between India and Pakistan, India and Bangladesh, India and Nepal, and Pakistan and Afghanistan. Additionally, SAARC member states are engulfed in multiple conflicts, for example, territorial disputes, tensions over cross-border terrorism allegations, tensions over refugees, and water conflicts (Ahmed, 2013). Political parties in all these nations shape citizens' attitudes, and to a large extent, even media seems to feed and fuel on such escalation of conflicts and assist breeding negative patriotism.

Regional cooperation of regional river basin partners is prerequisite for resolving water conflicts. Equitable share of riparian countries, mutual interest on increasing net benefits through development of projects and a wellcoordinated approach to water management issues for realising an optimum benefit from water resources must be respected as a fundamental premise for evolving a framework for conflict-free sustainable water sharing in the SAARC region.

\section{People and Water}

Themes of pollution, lack of government cooperation, surging population, climate change, industrialisation, agriculture, transboundary issues, and other changing lifestyle needs are reasons for changes to the water management strategies within the SAARC countries (Basu \& Shaw, 2013). Clean drinking water across much of South Asia is scarce and at times contaminated, especially to those living in areas of lower socioeconomic status who cannot access fresh drinking water within the home (Basu \& Shaw, 2013). Due to a lack of water treatment facilities in many SAARC countries, countless people consume unclean water which is harmful to their health (Price et al., 2014). Many experience admission to hospital for diseases and conditions such as cholera, typhoid, and diarrhoea (Basu \& Shaw, 2013). Furthermore, it is estimated that 40 per cent of child deaths in Pakistan are due to water-borne diseases (Pakistan Today, 17 April 2012). 
The long distances by which mainly females and children must travel to retrieve water to bring to their communities is a further burden on not only the everyday household chores but also the health and safety of these individuals (Basu \& Shaw, 2013; Pawar, 2014). Citizens of many SAARC countries believe that governments have not done enough to bring drinking water within appropriate proximity of many communities (ADB, 2013). Furthermore, citizens believe the government has failed to supply adequate storage in most cases; they feel water management is insufficient (ADB, 2013).

\section{Challenges of Water Crisis: Social Work Practice}

Links between water, poverty, health, and government and social work practice are real even though environmental issues including water have hardly found a place in the curriculum of social work. Although a few social work academics seem to recognise the need to construct an environmental interface with social work practice, the profession oddly seems to stay away from accepting a constructive challenge in the agenda of environment in social work (Pulla, 2013). While recognising societal dangers of environmental change, with a very minimalist approach and any sustained interest, consideration and debate around environmental change is imperative. Human populations living with low socioeconomic status are some of the worst affected by inadequate drinking water leading to increased health issues and higher rates of mortality (Basu \& Shaw, 2013; Price et al., 2014). The state and national government leaders of many SAARC countries have made insufficient progress towards addressing water management concerns (SHRDC, 2013). No longer is the water crisis an issue exclusive to those considered vulnerable and weak; there are concerns across the entire SAARC region (SHRDC, 2013).

Social work approaches are useful in evaluation and research; environmental education; community development; advocacy; influencing of social and environmental policy (Pawar, 2014). Before any serious steps can be undertaken by the social work profession towards building a presence in the climate change debate, social workers ought to turn their attention to building an understanding of what such an environmental understanding means for the professional practice (Pulla, 2013). However, a strong emphasis towards seeking improvement to the subjective wellbeing and quality of life of individuals, groups, families, and communities permeates from social work's and social policy's core (Ife, 2012; Pawar, 2013, 2014). Values of social work practice focus on bringing about social change through progressive movement towards maintaining human rights and social justice of people. They also challenge oppression from political and bureaucratic authority (Ife, 2012). Powerful national bodies such as National Association of Professional Social Workers in India (NAPSWI) have a great opportunity here to lead the rest of the SAARC nations in building a curricular initiative that would begin assisting a SAARC regional approach.

Social work has been found to be well suited to the mobilisation of people at the grassroots and advocacy. Furthering this by partaking in policy discourse and development would improve the quality of life and subjective wellbeing of those living in SAARC countries affected by the water crisis (Pawar, 2014). Clearly research plays an essential role in a social worker's acquisition of knowledge, which can be transferred to practice in producing evidence-based interventions to improve the lives of people (Grinnell \& Unrau, 2010; Rubin \& Babbie, 2009). As is evident in this paper, previous research undertaken within SAARC countries is invaluable to highlighting areas of much-needed attention and intervention; furthermore, there is a need for continued research by social workers and other professionals. Social work research has the power to affect social policy directly; social workers employed within policy research settings are responsible for monitoring and evaluating the effectiveness of policies put in place, this is of course guided by the social 
worker's research findings (Alcock \& Ferguson, 2012; Dickens, 2009). In SAARC countries, social workers in such positions would, therefore, have the ability to have direct input, and advocate for change, in policies that are found to be ineffective.

\section{Indian Case Study Illustrates Possibilities}

Empowerment-oriented community development is the process by which social workers enable communities to increase control over their lives through taking collective action (e.g., planning and advocating) to generate solutions to problems (Ife, 2013; Lawson, 2010). An example of social workers engaged in empowerment-oriented community development and advocacy in SAARC countries is in Shanin Nagar, India where there is no electricity, water lines, roads, or septic tanks (IRIN, 2006).

Women and their children must walk several kilometres to fetch water each day; city council has offered to improve their situation at the cost of $₹ 4,000$ (that is, US\$87) per household, an unaffordable price for people in this area (IRIN, 2006). For instance, social workers have been working alongside the Shanin Nagar community in advocating the government free or lower prices to obtain these much-needed water and sanitation infrastructures (IRIN, 2006). Social workers have been involved in attempting to help improve the hygiene practices of the people within this area; however, little can be done without the Indian government supplying the funds needed for necessary water infrastructure (that is, water sanitation plants and water lines; IRIN, 2006).

\section{The Rationale for Regional Cooperation}

Large segments of society in South Asia still do not have access to clean drinking water. Unhygienic water puts millions at risk of severe disease and death. With frequent droughts in India and Pakistan and with population growth in Nepal, and Bangladesh, water demands have increased. Both, urbanisation and industrialisation, have also resulted in a widening gap between the demand for and supply of water. This situation will be further aggravated by climate change (IPCC, 2008). For example, "in Pakistan and Western India, the future risk to groundwater would come from an increase in water demand for irrigation and other purposes from warmer temperature, unsustainable uses of this resource, and reduced recharge in drought years" (Mirza, $2007, p .5)$. It has been reported that with over 200 million people, the Ganges-BrahmaputraMeghna delta has experienced more than double the amount of water stress, since the India-Pakistan partition in 1947. This has resulted in Bangladesh and Southern West Bengal in India to experience water scarcity notwithstanding the massive increase in the use of groundwater (Brichieri- Colombi \& Bradnock, 2003, p.62; Sinha, 2006).

It is not only the increase in population stressing water resources in South Asia, as in the long-run water insecurity will be greater due to devastating impacts of climate change. According to an estimate, melting at the Dokriani glacier ${ }^{5}$ in 1998 was 20 metres compared to an annual average of 16.5 metres over 1993-1998. The $30.2 \mathrm{~km}$ long Gangotri glacier has been receding at an alarming rate, 364 metres between 1977 and 1990. Overall Himalayan rivers provide an estimated 8500 cubic $\mathrm{km}$ of water per annum out of which ten per cent comes from glacial melting to continue rivers during dry seasons (Mirza, 2007). More importantly, 15,000 Himalayan glaciers form a unique water reservoir supporting lifeline rivers, namely the Indus, Ganges and Brahmaputra flowing to Bhutan, Bangladesh, India, Nepal, and Pakistan (IPCC,2007a:493). ${ }^{6}$ It has been measured that already precipitation decline and droughts have already resulted in drying of wetlands and severe degradation of ecosystems in Pakistan, Bangladesh, and India (IPCC, 2008, p. 87).

\footnotetext{
${ }^{5}$ Dokriani glacier is one of the several hundred glaciers feeding the Ganges River (Mirza, 2007).

${ }^{6}$ The IPCC reports that if due to climate change the same trends of glacial melting continue then the Ganga, Indus, Brahmaputra, and other rivers could likely become seasonal rivers (IPCC, 2007a:493).
} 
In the early 21st century, environmentalists in South Asia began pondering over the swift melting of the glaciers, which is likely to have devastating impacts on countries depending on rivers emerging from glacial waters. Increasing environmental insecurities are seen as a threat to national, regional and global security (Sinha, 2006:601). Dyer (2008) predicted that by 2036, the Indus system would have no water and this will cause a life-and-death crisis for Pakistan, as most of the country's food is grown on land that is irrigated by the Indus river system. Considering various water security-related challenges, Dyer (2008) foresees a nuclear war between India and Pakistan, as the latter depends on rivers emanating from the Indian part of Kashmir. Moreover, according to him, it will be Pakistan going for the nuclear strike before India, if that ever happens, due to Pakistan facing the critical water and food insecurity challenges. Najam (2003: 59) does not envisage the possibility of violent bilateral conflicts over environmental issues in South Asia. However, he is apprehensive of the fact that environmental insecurity has the potential to exacerbate bilateral conflicts. Barnett and Adger (2005) also argue the uncertainty about the correlation between climate change and violent conflicts and therefore suggest more research exploring this critical dimension of climate change.

\section{SAARC's Response and Options}

In the present context, where there are multiple governance systems to influence policy at national levels, the role of SAARC, the regional organisation cannot be ignored. Although the future of SAARC is not known, there is definite merit in its role to intervene in the water crisis, given its viability and its enthusiasm for a shared future and shared regional security (Nikku \& Pulla, 2014). Cooperation in this area may also help SAARC in generating a desired level of interdependence among its members, which is also a prerequisite for a successful multilateralism. Keohane (1990, p.742) well articulates a major benefit of such interdependence:
Even if states were unitary decisionmakers, under conditions of interdependence their ability to attain their objectives would be increasingly affected by the actions of others. As interdependence rises, there- fore, the opportunity costs of not coordinating policy increase, compared with the costs of sacrificing autonomy because of making binding agreements. The result can be expected to be an increased demand for a multilateral agreement (1990, p. 742).

The SAARC region experiences many long-term and an increasingly devastating human management challenges (that is, water scarcity, food shortfall, energy shortage, and poverty) requiring cooperation from all SAARC countries (Ahmed, 2013; SHRDC, 2013). SAARC was founded in 1985 with a focus on assisting the economy to achieve adequate and sustainable human needs more efficiently by putting people at the centre of development (Ahmed, 2013). SAARC countries agreed upon to work together in the spirit of trust, understanding, and friendship to produce change through such means as policies targeted at improvement of wealth, better healthcare development, improved literacy, decreased poverty, and improved standards of living (Ahmed, 2013; SHRDC, 2013).

During the thirteenth SAARC Summit held on January 2006 in Bangladesh, SAARC outlined 22 priority goals for 2007-2012, which were adopted by the leaders and governments of SAARC countries. These goals pertain to four key areas: health (that is, maternal health, child health, affordable health-care, and improved hygiene and public health), education (that is, access to primary school for all children, completion of primary education, universal literacy, and quality education across all levels), environment (that is conservation of biodiversity, wetland conservation, a ban on dumping of hazardous waste, acceptable forest cover, water and social quality, and air quality,), and livelihood (that is, , eradication of hunger poverty, halve the proportion of people in 
poverty by 2010 , ensure adequate nutrition for the poor, ensure robust pro-poor growth, strengthen connectivity of poorer regions, reduce social and institutional vulnerabilities of the poor, women and children, ensure access to affordable justice, and ensure active participation of poor and of women in antipolicies and program; (SHRDC, 2013). It can be argued that these goals largely subsume the United Nations Millennium Development Goals, which has been renamed now as Sustainable Development Goals. Access to clean water plays a major role in many of these 22 goals; people's livelihood, health, and environment are highly dependent on access to clean water (SHRDC,2013).

SAARC countries had enormous potential to achieve all 22 goals; however, lack of commitment by state and national government leaders saw some goals, especially those pertaining to water management, not achieved across the SAARC region within the period 2007-2012 (SHRDC, 2013). There are still around 879 million people in SAARC countries who continue to be deprived of proper sanitary facilities meaning water supplies continue to be polluted by human waste; furthermore, 278 million people continue to have no access to clean drinking water (SHRDC, 2013). The condition of water sanitary facilitates and access to clean drinking water is gloomy across SAARC countries; Table 1 represents recent data gathered by the SAARC Human Resource Development Centre (2013), which suggests all countries, except for the Maldives and Sri Lanka, have made unsatisfactory progress towards implementing positive changes to water management.

\begin{tabular}{|l|l|l|l|}
\hline \multicolumn{5}{|c|}{ Table 1: Percentage with Access to Clean Drinking Water and Sanitation Facilities } \\
\hline Countries & No & Yes & To some level \\
\hline Afghanistan & $24 \%$ & $17 \%$ & $59 \%$ \\
\hline Bangladesh & $24 \%$ & $16 \%$ & $60 \%$ \\
\hline Bhutan & $50 \%$ & $25 \%$ & $25 \%$ \\
\hline India & $45 \%$ & $17 \%$ & $38 \%$ \\
\hline Maldives & $0 \%$ & $74 \%$ & $26 \%$ \\
\hline Nepal & $40 \%$ & $3 \%$ & $57 \%$ \\
\hline Pakistan & $15 \%$ & $5 \%$ & $81 \%$ \\
\hline Sri Lanka & $18 \%$ & $46 \%$ & $46 \%$ \\
\hline Source: The basis for this table is SAARC Human Resource Development Report 2013
\end{tabular}

Lack of clean drinking water and sanitation facilities is further pressured due to the $95 \%$ of water within the SAARC region that is used exclusively for agriculture; this is significantly higher than the global agricultural water use average of $70 \%$ (SHRDC, 2013). Overall, SAARC predicts issues surrounding water usage and access to increase significantly over the long term unless governments implement policy and invest capital into strategies designed to improve water management (SHRDC, 2013). Furthermore, SAARC recommends that SAARC countries focus on the successes of strategies implemented by the Maldives and Sri Lanka in achieving improved water management (SHRDC, 2013).

The data presented by SAARC in Table 1 and suggestions to follow strategies implemented in countries such as the Maldives and Sri Lanka may not necessarily be in the best interests of other SAARC countries. The Maldives relies heavily on desalinated seawater which is very expensive and likely to be unaffordable to the poor of other SAARC countries; furthermore, countries such as Afghanistan, Bhutan, and Nepal are not situated on oceans (Basu \& Shaw, 2013). Sri Lanka relies heavily on internal renewable water resources such as groundwater, rivers, and streams; a number of other SAARC countries do not necessarily have suitable access to clean water from such resources (Basu \& Shaw, 2013).

SAARC, as an intergovernmental organisation, is yet to work towards equitable sharing and efficient use of regional waters in South Asia. However, considering the water crisis, regional 
leaders' emphasised conservation of water resources in South Asia and for this purpose initiated combining practices of rainwater harvesting and river basin management towards sustainable use of water resources (SAARC, 2008b,p.3). SAARC has the potential to work towards coordinating national water conservation policies of its member states, to bring expertise in water management and conversation to the regional level. While working towards sustainable use of water resources in South Asia, SAARC has to work at the community level through awareness campaigns.

\section{Public Good and Private Profit Debate}

Publicly run utilities in developing countries have been criticised for providing unreliable supply and sanitation (Brocklehurst, 2002). Literature on public utilities in South Asia points to limitations imposed by inadequate infrastructures, wastage, and administrative inefficiencies. Furthermore, the propositions that favour private provision in the developing world are supported by notions that public water and sanitation utilities have failed and continued to be of poor quality and coverage.

As said earlier, once a resource of the commons- water and it is privatisation of has generated much controversy, due to major societal considerations as an essential human need (Rogers et al. 1998). In such arguments, water and sanitation are often defined as goods to which people have a right, regardless of their ability to pay.

Debates around corporatisation and privatisation have also occurred in SAARC countries with the governments already encouraging private enterprises and even multinational corporate involvement. In many capital cities in India, water no longer is able to be tapped through the municipal supplies. Private sector provision of water and sanitation, although not pervasive is widely known since the early nineties. What was once a resource of commons, the state seems to have handed over possession to corporate and private enterprises that are able to supply drinking water by large cans. It is unclear as to how privatisation can assist SAARC nations to achieve the Millennium Development Goals of halving the number of people without access to water and sanitation. There is clearly no discussion on this as SAARC forums have not pondered over this as a community of nations.

There are already mechanisms within SAARC that can support and mainstream communitylevel initiatives on water security and management. In this regard, it is important to highlight that the role of the SAARC Development Fund (SDF), which has its secretariat in Bhutan. It focuses on the welfare of South Asians, for example, improving their quality of life; therefore, we argue that SDF should work with South Asian civil society organisations to formulate social policy in relation to water resources. So far, it has funded projects in selected SAARC countries on strengthening water, sanitation, and hygiene, but direct work there is a need to support projects focusing on water infrastructure and water security in the region. But clearly within the region there is a general paranoia with all SAARC governments about the role of nonstate actors and civil society organisations. A general tendency to perceive non-state actors and civil society organisations as anti-state and anti- national interests rather than people centred and human rights centred is growing within all SAARC bureaucracies. A recent example is from India, where its federal government officials said police have also been asked to track activities of NGOs engaged in protests against various "development projects" in states (Tripathi, 2018).

On the question of what can SAARC do for water resources management at a regional level in South Asia, it is important to draw lessons from the Association of Southeast Asian Nations (ASEAN). There can be many justifications for using ASEAN as a model for SAARC, but most of all ASEAN continues to be seen as a successful regional organisation in South Asia. There is an ever-growing interest among SAARC leadership since its inception in learning from ASEAN. In addition, the regional dynamics are somewhat similar due to 
Indonesia's dominance in Southeast Asia and India's supremacy in South Asia (Iyer 2008, 2010) and The London Post, 2017). There have also been bilateral tensions between the member states in the respective regions. Most recently, this was evident in 2013 when a delegation of SAARC officials, including its then secretary general, visited the ASEAN Secretariat to learn more about its operational mechanisms. Finally, there is already some engagement of member states of both organisations in SAARC and ASEAN, for example, Myanmar is a SAARC Observer, India is a member of the East Asia Summit, and the following SAARC states are part of the ASEAN Regional Forum: Bangladesh, India, Pakistan and Sri Lanka.

The ASEAN's leadership is aware of the challenges faced by its member states, therefore, it document 'ASEAN Socio-Cultural Community Blueprint 2009-2015' focus on promoting the sustainability of freshwaters resources. The organisation has the ASEAN Strategic Plan for Action on Water Resources Management that aims to ensure sustainable access to drinking water and water conservation through regional cooperation. For coordinating among the member states, ASEAN has the Working Group on Water Resource Management. Despite political hurdles facing SAARC, it is possible for the organisation to follow ASEAN's roadmap to begin working on managing water resources. Such a move will help SAARC align more closely with commitments of its member states under the International Convention of Economic, Cultural and Social Rights, which has been ratified by all SAARC members except for Bhutan. ${ }^{7}$ The countries that have ratified are under obligation to develop and implement policies to ensure water as a human right. Considering limitations placed in the SAARC Charter, such as non-interference in internal matters of member states, it is also a viable option for the organisation to work on issues that are noncontroversial, such as access to clean drinking

\footnotetext{
${ }^{7}$ Bhutan is among the 25 UN member states that have not either signed or ratified the Convention.
}

water, and water conservation. This may lead to greater awareness of water security in South Asia, something that may indirectly but positively affect cross-border tensions over Transboundary Rivers.

\section{Conclusion}

From a global standpoint, there appears to be some optimism about the free market systems such that occur through privatisation and corporatisation and the potential of all new technologies that have potential to force adjustments in the business as usual (BAU) attitudes and practices of people and societies in general. However with a large bane of low income families that reside in the SAARC region countries, a question that comes up is, will these adjustments in turn call for changes in values and lifestyles in the South Asian context? And what form and shape those changes will look like is a significant question that SAARC nations need to deliberate upon. Given that there is high growth in national incomes in South Asia, the tendency seems to push up the per capita domestic water use while structural and technological changes are to assist in pushing the demands down. If privatisation and corporatisation of water management is pointed as a solution, the inherent contradictions between private profits and public good are to be teased out as there are in these countries, millions of low-income households. Such solutions hang like the Damocles sword that speaks to the perilous nature of happiness, in this context, the task of quenching the thirst of the poor households, within the SAARC nations would not be possible unless the private sector participation is concessionary in nature and recognises water as a public good which is non excludable and the poor cannot be deprived of consuming it.

In this paper, we endeavoured to identify strategic ways of resolving the South Asian water crises that would benefit SAARC countries. Our review explored the current water crises in SAARC countries, especially in connection to water management, water resources, and water-related people-centred issues, attitudes towards transboundary river infrastructures, the role of 
SAARC to intervene in the water crisis, and the role of social work and related professions in assisting with appropriate water management. SAARC countries are experiencing similar, but various, water-related crises relating to water resources management. SAARC member states also have similar dynamics about the use and misuse of water, for instance, the extensive use of water in agriculture and water contamination mainly due to industrial waste dumped in waters (Roth et al., 2014). Further, the investigation is required into the water management and resource issues of SAARC countries, which appear to centre on challenges for government bodies, such challenges as increasing population, domestic and international conflict, and domestic mismanagement and decreased the quality of water. Obvious is the need for a joint effort by the governments of SAARC countries, especially those connected to the south Asian mainland, in attempting to address water-related issues.

Furthermore, is the need for countries to work alongside SAARC in attempting to reach, set out, and achievable development goals. While there are defined human rights standards by SAARC, the member states are signatories to international agreements that demand formulation and implementation of social policy on water resources management by considering 'water' a fundamental human right. SAARC as a young and development regional organisation needs the political will to flourish and work in practical ways for the welfare of South Asia. In this regard, the organisation can learn from measures taken by ASEAN. Social work and human services management should continue to be involved in research, policy research and writing, community development, and advocacy to fight for the human rights, and improved subjective well-being and quality of life of all people living in SAARC countries.

\section{References}

Ahmed, Z. S. (2013). Regionalism and regional security in South Asia: The role of SAARC. New York: Routledge.

Alcock, P., \& Ferguson, H. (2012). Social policy and social work. In S. Becker, A. Bryman \&H. Ferguson (Eds.), Understanding research for social policy and social work:
Themes, methods and approaches (pp. 4-11). Bristol: The PolicyPress.

Alcamo, J., Henrichs, T., \& Rosch, T. (2000). World Water in 2025-Global modelling and scenario analysis for the World Commission on Water for the 21st Century, Report A0002, Centre for Environmental Systems Research. Kassel: University of Kassel.

Amarasinghe, U. A., Mutuwatta, L., \& Sakthivadivel, R. (1999). Water Scarcity Variations within a Country: A Case Study of Sri Lanka, retrieved on 18 January 2017 from, http://www.iwmi.cgiar.org/Publications/IWMI_Research _Reports/PDF/pub032/Report32.pdf

Asian Development Bank and Asian-Pacific Water Forum. (2013). Asian water development outlook 2013 : Measuring water security in Asia and the Pacific. Manila: ADB.

Barnett, J. \& Neil, A. (2005). Security and climate change: towards an improved understanding, Human Security and Climate Change, Oslo.

Basu, M., \& Shaw, R. (2013). Water policy, climate change and adaptation in South Asia, International Journal of Environmental Studies, 70, 175-191.

Biswas, A. K. (2011). Cooperation or conflict in transboundary water management: case study of South Asia, Hydrological Sciences Journal, 56(4) 662-670

Brichieri-Colombi, S., \& Bradnock, R. W. (2003). Geopolitics, water and development in South Asia: cooperative development in the Ganges-Brahmaputra delta, The Geographical Journal, 169 (1), 43-64.

Borcklehurst, C. (2002) (editor), New designs for water and sanitation transactions: making private sector participation work for the poor, PPIIAF and Water and Sanitation Programme, Washington DC.

Dickens, J. (2009). Social work and social policy: An

introduction. New York: Routledge.

Dyer, G. (2008). Climate Wars. Carlton North: Scribe Publication.

Earle, A., Jagerskog, A., \& Ojendal, J. (2013). Introduction: Setting the scene for transboundary water management approaches. In A. Earle, A. Jagerskog, \& J. Ojendal (Eds.), Transboundary watermanagement (pp. 1-12). London: Earthscan. 
Ebrahim, Z.T. (2016, May 12). Pakistan's population bomb: 240 million in 2030. Dawn. Retrieved from https://www.dawn.com/news/1221289

Gupta, A,D., Babel, M. S., Albert, X., \& Mark, O. (2005). Water Sector of Bangladesh in the Context of Integrated Water Resources Management: A Review. International Journal of Water Resources Development, 21 (2) pp. 385398.

Guppy, L., \& Anderson, K. (2017). Water Crisis Report. Hamilton: United Nations University Institute for Water, Environment and Health.

Grinnell, R. M., \& Unrau, Y. A. (2010). Social work research and evaluation: Foundations of evidencebased practice. New York: Oxford University Press.

Human Development Centre. (2013). Human development in South Asia 2013. Lahore: HDC.

Ife, J. (2012). Human rights and social work: Towards rightsbased practice (3rd ed.). Melbourne: Cambridge University Press.

IRIN, (2006). Integrated Regional Information Networks. (Running dry: The humanitarian impact of the global water crisis. Nairobi: IRIN.

IPCC (2007). Climate change 2007: impacts, adaptation and vulnerability: summary for policymakers. In Working Group I. Geneva: Intergovernmental Panel on Climate Change (IPCC).

IPCC (2008). Climate Change and Water. In IPCC Technical Paper. Geneva: Intergovernmental Panel on Climate Change (IPCC).

Iqbal, A. R. (2010). Water Shortage in Pakistan - A Crisis around the Corner. ISSRA Papers, 2(2), 1-13.

Iyer, R. R. (2008, September 17). Water in India-Nepal relations. The Hindu. Retrieved from https://www.thehindu.com/todays-paper/tpopinion/Water-in-India-Nepalrelations/article15304717.ece

lyer, R. R. (2010, October 29). Approach to a New National Water Policy. The Hindu. Retrieved from http://www.hindu.com/2010/10/29/stories/201010296 3801400.html

Joshi, M. N. (2013). National River Linking Project of India, Hydro Nepal, Issue No. 12 January, 2013 p.13-19. Retrieved from
https://www.nepjol.info/index.php/HN/article/viewFile/9 026/7413

Kamal, S. S. (2009). Use of Water for Agriculture in Pakistan: Experiences and Challenges. Retrieved from http://digitalcommons.unl.edu/cgi/viewcontent.cgi?articl e=1012\&context=researchecondev

Keohane, R. O. (1990). Multilateralism: An Agenda for Research, International Journal, 45(4), 731-764.

Kugelman, M. (n.d.). Safeguarding South Asia's water security. Retrieved from http://www.indiaseminar.com/2011/626/626_michael_kugelman.htm

Lawson, H. A. (2010). Empowering people, facilitating community development, and contributing to sustainable development: The social work of sport, exercise, and physical education programs, Sport, Education and Society, 10, 135-160. doi: $10.1080 / 1357332052000308800$

London Post, (2017, January 18). India's Water Issues with Bangladesh, Nepal, and Bhutan. Retrieved from https://thelondonpost.net/indias-water-issues-withbangladesh-nepal-and-bhutan/

Mastoor, M. (2009). Environmental degradation: Focus on water scarcity in South Asia. Islamabad: Institute of Regional Studies.

Memon, A. R. (2014, February 21). Impending water wars in South Asia. The Express Tribune. Retrieved from https://tribune.com.pk/story/674611/impending-waterwars-in-south-asia/

Mirza, Monirul (2007). Climate change, adaptation and adaptive governance in water sector in South Asia, Institute for Environmental Studies, Vrije Universiteit Amsterdam, retrieved on 30 July 2018 from, http://www.2007amsterdamconference.org/Downloads /AC2007_Mirza.pdf.

Mohan, V. (2014). Interlinking of rivers to get new push underModigovernment. New Delhi, India: The Times of India.

Nair, A. (2014). Narmada waters to fuel Coca Cola's new bottling plant at Sanand. New Delhi, India: Financial Express.

Najam, A. (2003). The human dimensions of environmental insecurity: some insights from South Asia. In Environmental Change and Security Project Report, edited 
by Geoffrey D. Dabelko (pp. 59-73). Washington DC: The Woodrow Wilson Center.

Nikku, B. R., \& Pulla, V. (2014). Global Agenda for Social Work and Social Development: Voices of the social work educators from Asia International Social Work, 57(4)373385

Pakistan Today (2012). Polluted water causes $40 \%$ of deaths in Pakistan annually, Pakistan Today, 17 April 2012. Retrieved from https://www.pakistantoday.com.pk/2012/04/17/pollute d-water-causes-40-of-deaths-in-pakistan-annually/

Patkar, M., Kanvache, B., Tomar, D., Paateedar, V., \& Yadav, R. (2014). NBA's response to drawing of Narmada water for Coca-Cola plant. Barwani: NBA

Pawar, M. (2010). Looking outwards: Teaching international social workin Asia.Social WorkEducation: The International Journal, 29, 896-909.

Pawar, M. (2013). Water insecurity: A case for social policy action by social workers. Australian Social Work, 66 (2), pp. 248-260.

Pawar, M. (2014). Water and Social Policy. New York: Palgrave Macmillan.

Price, G., Alam, R., Hasan, S., Humayun, F., Kabir, M. H., Karki, C. S., \& Mittra, S. (2014). Attitudes to water in South Asia. London: Chatham House.

Pulla, V. (2013). Critical Essay: Environmentalism and Social Work. Rural Society, 22(3), 263-268., doi:10.5172/rsj.2013.22.3.263

Quaddumi, H. (2008). Practical approaches to transboundary water benefit sharing. London: Overseas Development Institute.

Reid, K. (2018, May 17). Global water crisis: Facts, FAQs, and how to help. Retrieved from https://www.worldvision.org/clean-water-newsstories/global-water-crisis-facts

Reich, D., \& Pearson, C. (2012). Irrigation Outreach in Afghanistan: Exposure to Afghan Water Security Challenges. Journal of Contemporary Water Research \& Education, 149(1), 33-40.

Roth, D., Zwarteveen, M., Joy, K. J., \& Kulkarni, S. (2014). Water rights, conflicts, and justice in South Asia. Local Environment, 19(9), 947-953.
Rubin, A. and Babbie, E. (2009). Essential research methods for social work. Belmont, CA: Cengage Learning.

SHRDC (2013). SAARC Human Resource Development Centre, SAARC development goals: Achievements, gaps and way forward. Islamabad: SAARC Human Resource Development Centre.

SAARC (2008). Declarations of SAARC Summits: 1985-2008. Kathmandu:South Asian Association for Regional Cooperation (SAARC).

Shoukat, A. \& Pulla, V. (2017). Desert Dwellers' Meaning and Existence of Spirituality: A Gendered Case Study of Cholistan, Pakistan. Space and Culture, India, https://doi.org/10.20896/saci.v5i2.278

Sinha, U. K. (2006). Environmental stresses and their security implications for South Asia, Strategic Analysis, 30(3), 599-618.

Singh, S. (2014). Women, Environment and Sustainable Development: A Case Study of Khul Gad Micro Watershed of Kumoun Himalaya, Space and Culture, India, 1(3) 53-64. https://doi.org/10.20896/saci.v1i3.45

Singh, S. B. (2015). Women as Milieu Managers in Integrated Watershed Management: Perspectives from the Hilly Areas of Uttarakhand. Space and Culture, India, 2(4), 71-79. https://doi.org/10.20896/saci.v2i4.130

Swain, A. (2018, April 7). It Is Water Not China That Has Ruined Nepal's Relations With India. Outlook. Retrieved from https://www.outlookindia.com/website/story/it-iswater-not-china-that-has-ruined-nepals-relations-withindia/310684

Tripathi, R. (2018, November 02). Centre to states: Track NGOs for 'anti-national' activities. Retrieved November 3, 2018, from https://indianexpress.com/article/india/centreto-states-track-ngos-for-anti-national-activities-5430272/

Unicef Media Centre (n.d) Media Centre. Retrieved from

https://www.unicef.org/esaro/5440_2016_coll ecting-water.html

Uprety, K. and Salman, M. A. (2011). Legal aspects of sharing and management of transboundary waters in South Asia: Preventing conflicts and promoting cooperation. Hydrological Sciences Journal, 56, 641-661. 


\section{Acknowledgements}

The authors are grateful to all anonymous referees for suggestions to improve this article. Additionally, the principal author wishes to acknowledge Dr Rituparna Bhattacharyya, for meticulous editing; and $\mathrm{Mr}$ Bharath Bhushan
Mamidi, Sociologist and Director, Centre for Action Research and People's Development for reading the earlier drafts and Ms. Reeti Mathur, Research Associate to the principal author for working with him on water and South Asia related research projects. 